\title{
Endogenous Ganglioside GM1 Modulates L-Type Calcium Channel Activity in N18 Neuroblastoma Cells
}

\author{
Robert O. Carlson, ${ }^{a}$ Daniel Masco, Gary Brooker, and Sarah Spiegel \\ Department of Biochemistry and Molecular Biology, Georgetown University Medical Center, Washington, DC 20007
}

\begin{abstract}
Digital imaging fluorescence microscopy was used to investigate the effect of the $B$ subunit of cholera toxin on calcium homeostasis in neuroblastoma $\mathrm{N} 18$ cells. The $B$ subunit, which binds specifically to ganglioside GM1 in the outer leaflet of the cell membrane, was found to induce a sustained increase of intracellular calcium concentration $\left(\left[\mathrm{Ca}^{2+}\right]\right)$. The increase in $\left[\mathrm{Ca}^{2+}\right]$, was not observed in the absence of extracellular calcium, or in the presence of the calcium chelator EGTA, and was blocked by nickel. The B subunit was also found to induce an influx of manganese ions, as indicated by a quench of the intracellular fura-2 fluorescence. These data suggest that the $B$ subunit induces an increase in calcium influx in $\mathbf{N} 18$ cells. Potassium-induced depolarization also stimulated manganese influx; however, after the onset of depolarization-induced influx, the $B$ subunit had no further effect. This occlusion suggests involvement of voltage-dependent calcium channels. Treatment with BayK8644, a dihydropyridine agonist selective for L-type calcium channels, induced manganese influx that was not altered by the $B$ subunit and apparently blocked the effect of the $B$ subunit itself. Furthermore, the dihydropyridine L-type channel antagonists niguldipine or nicardipine completely inhibited $B$ subunit-induced manganese influx. Thus, the $B$ subunit-induced manganese influx is likely due to activation of an L-type voltage-dependent calcium channel. Spontaneous influx of manganese ions was also inhibited by nicardipine or niguldipine and by exogenous gangliosides. Ganglioside GM1 was more potent than GM3, but globoside had no significant effect. The modulation of L-type calcium channels by endogenous ganglioside GM1 has important implications for its role in neural development, differentiation, and regeneration and also for its potential function in the electrical excitability of neurons.
\end{abstract}

[Key words: ganglioside GM1, B subunit of cholera toxin, L-type calcium channels, neuroblastoma]

Vertebrate neurons are enriched in gangliosides, sialic acidcontaining glycosphingolipids, particularly those of the gangliotetraose series including ganglioside GM1 (Svennerholm, 1963;

\footnotetext{
Received May 27, 1993; revised Sept. 29, 1993; accepted Oct. 4, 1993.

This work was supported by Research Grants $3018 \mathrm{M}$ from The Council for Tobacco Research and I R 29 GM 39718 from the National Institutcs of Hcalth. We thank Dr. M. Nirenberg for providing neuroblastoma N18 cells.

Correspondence should be addressed to Dr. Sarah Spiegel, Department of Biochemistry and Molecular Biology, Georgetown University Medical Center, 357 Basic Science Building, 3900 Reservoir Road NW, Washington, DC 20007.

aPresent address: Hoechst-Roussel Pharmaceuticals, Inc., Department of Biological Research, Somerville, NJ 08876.

Copyright (c) 1994 Society for Neuroscience $0270-6474 / 94 / 142272-10 \$ 05.00 / 0$
}

Hakomori, 1990) and more complex derivatives. Ganglioside synthesis increases in synchrony with the period of most active nervous system development in many species. These observations originally spawned the idea that gangliosides may play a role in the process of neuronal development and maturation (Ledeen and $\mathrm{Wu}, 1992$ ). Subsequently, exogenous gangliosides have been found to have marked effects on cell growth and to promote differentiation in a variety of neuronal cell types (reviewed in Hakomori, 1990; Ledeen and Wu, 1992). The monosialoganglioside GM1, in particular, when added to cells has also been shown to enhance sprouting of regenerating nerves (Schengrund, 1990), to enhance repair of CNS damage (Ledeen, 1984), and to ameliorate recovery from experimental Parkinson's disease in primates (Schneider et al., 1992). Moreover, ganglioside GM1 is now being used in clinical trials in human neurological disorders, including spinal cord injuries (Geisler et al., 1991) and stroke (Argentino et al., 1989). In spite of the apparent therapeutic value of ganglioside GM 1 , its mechanism of action remains obscure.

Attempts to elucidate the physiological mechanisms underlying ganglioside GM1-induced neuritogenesis have identified some potentially relevant pathways. Most notable are reports of changes in protein kinase activity (Goldenring et al., 1985; Cimino et al., 1987; Benfenati et al., 1991) and in intracellular calcium homeostasis (Spoerri et al., 1990; Wu et al., 1990; Hilbush and Levine, 1991). Ganglioside GM1 had a dual effect on calcium/calmodulin-dependent protein kinase II, stimulating activity and autophosphorylation at low concentrations (Goldenring et al., 1985; Cimino et al., 1987) whereas at high concentrations activity was decreased by noncompetitive inhibition of calmodulin binding to the enzyme (Benfenati et al., 1991). GM1-mediated stimulation of calcium influx and a resulting activation of calcium/calmodulin-dependent protein kinase has been implicated recently as a possible mechanism for GM1 potentiation of NGF-induced neuritogenesis in pheochromocytoma PC12 cells (Hilbush and Levine, 1991). Roisen and colleagues demonstrated that the GM1-induced neuritogenesis in Neuro-2a neuroblastoma cells was diminished in the absence of extracellular calcium, and that exogenous GM1 stimulated an increase in cytoplasmic free calcium in these cells as determined by electron probe elemental analysis (Spoerri et al., 1990). Similarly, Ledeen and colleagues reported that a mixture of bovine brain gangliosides was only effective at inducing neuritogenesis in Neuro-2a cells in the presence of extracellular calcium, a phenomenon potentially related to an increase in both calcium influx and efflux induced by the ganglioside mixture (Wu et al., 1990). In addition, ganglioside GM1 and some of its analogs antagonize glutamate toxicity by preventing protracted increases in intracellular free calcium (De Erausquin et 
al., 1990; Manev et al., 1990). While these numerous examples illustrate the potential of exogenous ganglioside GM1 for affecting various physiological phenomena by its effect on calcium regulation, the mechanism of these effects has not yet been investigated nor has it been shown that these effects reflect the actions of endogenous ganglioside GM1.

To address the potential function of ganglioside GM1 in cell growth regulation and differentiation, we have extensively used the B subunit of cholera toxin, a protein that binds specifically to ganglioside GM1 and, due to its oligomeric structure, can cross-link the ganglioside (reviewed in Spiegel, 1991; Olivera and Spiegel, 1992). Using this approach, we have accumulated important clues on the role of ganglioside GM1 in cellular proliferation, differentiation, and signal transduction in a variety of cellular systems (Spiegel et al., 1985; Dixon et al., 1987; Spiegel and Fishman, 1987; Spiegel, 1988, 1989a,b, 1990; Spiegel and Panagiotopoulos, 1988; Mulhern et al., 1989; Buckley et al., 1990; Masco et al., 1991). Our finding that the sole known transmembrane signaling system modulated by ganglioside GM1 in resting thymocytes (Dixon et al., 1987) and quiescent fibroblasts (Spiegel and Panagiotopoulos, 1988; Spiegel, 1989a,b) is cytosolic frec calcium has important implications, since calcium plays a central role in regulation of a myriad of critical physiological processes including cell proliferation, differentiation, transformation, smooth muscle contraction, and endocrine and exocrine secretion.

Recently, we found that the B subunit of cholera toxin inhibited the growth of N18 neuroblastoma cells and induced pronounced differentiation, with an increase in neurite outgrowth with branched neurites and spinelike processes (Masco et al., 1991). Numerous studies have shown that calcium plays a major role in these two divergent processes (Kater et al., 1988; Tsien et al., 1988; Kater and Mills, 1991). Furthermore, it has been suggested that each component of neurite outgrowth, including sprouting, elongation, and growth cone motility, is regulated by very specific, optimal changes in intracellular calcium (Mattson et al., 1988; Kater and Mills, 1991). In this report, we used digital imaging fluorescence microscopy to follow changes in intracellular calcium within single neurons and found that interaction of the B subunit with endogenous ganglioside GM1 stimulated a persistent increase in intracellular calcium in N18 cells likely due to activation of L-type voltage-dependent calcium channels.

\section{Materials and Methods}

Materials. The B subunit of cholera toxin was from List Biological Labs (Campbell, CA). Dulbecco's modified Eagle's medium (DMEM) and fetal calf serum were from GIBCO (Grand Island, NY). Fura-2/acetoxymethyl ester (fura-2/AM) was purchased from Molecular Probes, Inc. (Eugene, OR). Gangliosides wcre from Matrcya (Plcasant Gap, PA). Nicardipine and niguldipine were from Research Biochemicals Inc. (Natick, MA). BayK8644 was from Calbiochem (La Jolla, CA). Cloned B subunit was produced as recently described (Van de Walle et al., 1990).

Cell culture. The murine neuroblastoma cell line N18 was kindly provided by Dr. M. Nirenberg, NHLBI, NIH. Stock cultures of cells were maintained in high-glucose DMEM supplemented with $5 \%$ fetal bovine serum in a humidified atmosphere of $5 \% \mathrm{CO}_{2}, 95 \%$ air at $37^{\circ} \mathrm{C}$. For $\mathrm{Ca}^{2+}$ measurements, the cells were seeded and grown on poly-Dlysine-coated glass cover slips contained in six-well cluster tissue culture dishes $(6 \times 34 \mathrm{~mm}$ wells; Costar, Cambridge, MA) at a density of 2.5 $\times 10^{5}$ to $5 \times 10^{5}$ cells $/$ well. Cells were used $3-4 \mathrm{~d}$ after seeding.

Measurements of cytoplasmic free $\mathrm{Ca}^{2+}$ concentration. Digital imaging fluorescence microscopy was used to determine intracellular free $\mathrm{Ca}^{2+}$ concentrations $\left(\left[\mathrm{Ca}^{2+}\right]_{i}\right)$ as described previously (De Erausquin et al., 1990; Zhang et al., 1991). Briefly, N18 cells grown on glass coverslips were washed with DMEM and were loaded with fura-2/AM $(5 \mu \mathrm{M})$ for $45 \mathrm{~min}$ at $37^{\circ} \mathrm{C}$ in DMEM. For imaging, cells were incubated in DMEM (phenol red free) or buffered saline (154 mM NaCl, $5.6 \mathrm{~mm} \mathrm{KCl}, 1.2$ mм $\mathrm{MgCl}_{2}, 1.8 \mathrm{~mm} \mathrm{CaCl}_{2}, 4.6 \mathrm{gm} /$ liter glucose, $20 \mathrm{~mm}$ HEPES, $\mathrm{pH}$ 7.4) and changes in fura- 2 fluorescence in single cells were monitored by dual wavelength simultaneous detection imaging using an Attofluor Digital Fluorescence Microscopy System (Atto Instruments, Inc., Rockville, $\mathrm{MD}$ ). $\left[\mathrm{Ca}^{2+}\right]_{i}$ was determined from the ratio of fura-2 fluorescence emissions after excitation at the wavelengths of 334 and $380 \mathrm{~nm}$ and calibrated with external standards (De Erausquin et al., 1990; Zhang et al., 1991).

Measurement of $\mathrm{Mn}^{2+}$ influx. $\mathrm{Mn}^{2+}$ binds to fura-2 with a much greater affinity than $\mathrm{Ca}^{2+}$. In contrast to $\mathrm{Ca}^{2+}$, which enhances fura-2 fluorescence, $\mathrm{Mn}^{2+}$ binding quenches fura-2 fluorescence. Since $\mathrm{Mn}^{2+}$ is not freely permeable across cell membranes, a quenching of or decrease in the fluorescence intensity of intracellular fura- 2 in the presence of medium containing $\mathrm{Mn}^{2+}$ is indicative of $\mathrm{Mn}^{2+}$ influx into cells (Merritt et al., 1989; Jacob, 1990; Rink, 1990). To assay for $\mathrm{Mn}^{2+}$ influx, neuroblastoma N18 cells were loaded with fura-2 as described above. Fluorescence intensity due to excitation at both 334 and $380 \mathrm{~nm}$ was measured in single cells in $\mathrm{Ca}^{2+}$-free buffered saline using the digital imaging fluorescence microscopy. The effect of the presence of $\mathbf{M n}^{2+}$ alone or in combination with other agents was based upon changes in the rate of decrease of fluoresence intensity at both 334 and $380 \mathrm{~nm}$.

\section{Results}

$B$ subunit induces an increase in $\left[\mathrm{Ca}^{2+}\right]_{\mathrm{i}}$

Changes in $\left[\mathrm{Ca}^{2+}\right]$, were monitored in N18 cells loaded with fura-2 using digital imaging fluorescence microscopy. The $\mathrm{B}$ subunit of cholera toxin induced an increase in $\left[\mathrm{Ca}^{2+}\right]_{i}$ (Fig. 1) that occurred over a period of $10-20 \mathrm{~min}$, reaching a new steadystate level that was more than twofold higher than the resting $\left[\mathrm{Ca}^{2+}\right]_{i}$ (Fig. 1A). After washing to remove free B subunit, no further change occurred (Fig. $1 B$ ). Subsequent reapplication of $\mathrm{B}$ subunit resulted in an additional increase in $\left[\mathrm{Ca}^{2+}\right]_{i}$ (Fig. 1B).

These results were obtained with commercially available $B$ subunit that was originally purified from cholera holotoxin. Cholera holotoxin is composed of one A and one B subunit. The A subunit can stimulate increases in intracellular cAMP, and therefore contamination of $\mathrm{B}$ subunit preparations with small amounts of $A$ subunit could complicate the interpretation of results obtained with $B$ subunit purified from holotoxin. Cloned B subunit from a mutant strain of Vibrio cholerae that lacks the gene for the A subunit (Van de Walle et al., 1990) and therefore is completely free of contaminating A subunit, stimulated an increase in $\left[\mathrm{Ca}^{2+}\right]_{i}$ that was indistinguishable from the effect of the B subunit derived from holotoxin $(n=5)$. This result precludes involvement of A subunit-stimulated increases in cAMP in the observed induction of increases in $\left[\mathrm{Ca}^{2+}\right]_{i}$.

$B$ subunit-induced increases in $\left[\mathrm{Ca}^{2+}\right]_{i}$ were not observed in the absence of $\mathrm{Ca}^{2+}$ in the medium (Fig. 2). In the presence of $\mathrm{B}$ subunit, an increase in $\left[\mathrm{Ca}^{2+}\right]_{i}$ was observed immediately after addition of $\mathrm{Ca}^{2+}$ to the medium, whereas addition of $\mathrm{Ca}^{2+}$ by itself had no effect. Similarly, the B subunit did not stimulate an increase in $\left[\mathrm{Ca}^{2+}\right]_{i}$ in the presence of $5 \mathrm{~mm}$ EGTA (data not shown).

The presence of $\mathrm{Ni}^{2+}$ was also found to inhibit the B subunitinduced increase in $\left[\mathrm{Ca}^{2+}\right]_{i}$ (Fig. 3). Complete inhibition occurred when addition of $\mathrm{Ni}^{2+}$ preceded the exposure to $\mathrm{B}$ subunit (Fig. 3A). After onset of the B subunit-induced increase in $\left[\mathrm{Ca}^{2+}\right]_{i}$, addition of $\mathrm{Ni}^{2+}$ led to an immediate cessation of the increase (Fig. $3 B$ ). $\mathrm{Ni}^{2+}$ is one of several metal ions that can block $\mathrm{Ca}^{2+}$ influx though voltage-gated (Lansman et al., 1986) or receptoroperated calcium channels (Merritt et al., 1989) or through reverse $\mathrm{Na}^{+} / \mathrm{Ca}^{2+}$ exchange (Kaczorowski et al., 1989). Therefore, the inhibitory action of $\mathrm{Ni}^{2+}$ together with the dependence on 
Figure 1. Effect of $\mathrm{B}$ subunit on $\left[\mathrm{Ca}^{2+}\right]_{\text {i. }}$. $A$, Neuroblastoma $\mathrm{N} 18$ cells were loaded with fura-2 and $\left[\mathrm{Ca}^{2+}\right]_{i}$ was monitored as described in Materials and Methods. B subunit (180 nM) was added at the time indicated by the arrow. $A$, Response of an individual cell from a representative experiment in which 16 of 16 cells displayed a similar steadystate increase in $\left[\mathrm{Ca}^{2+}\right]_{i} . B$, B subunit ( $360 \mathrm{nM}$ ) was originally added to N 18 cells at the indicated time. A wash interrupted the ensuing increase in $\left[\mathrm{Ca}^{2+}\right]$. The cells were then reexposed to $B$ subunit. $C$, A histogram depicts the distribution of $\left[\mathrm{Ca}^{2+}\right]_{i}$ in single N18 cells at steady-state before and after addition of $B$ subunit (180 nM), accumulated from 12 separate experiments. An increase in $\left[\mathrm{Ca}^{2+}\right.$, accompanied the addition of B subunit in 213 of 280 cells. The average calcium concentration was $61 \pm 2 \mathrm{nM}( \pm$ SEM $)$ for unstimulated cells, increasing to $148 \pm 6 \mathrm{nM}( \pm \mathrm{SEM})$ after addition of $B$ subunit.

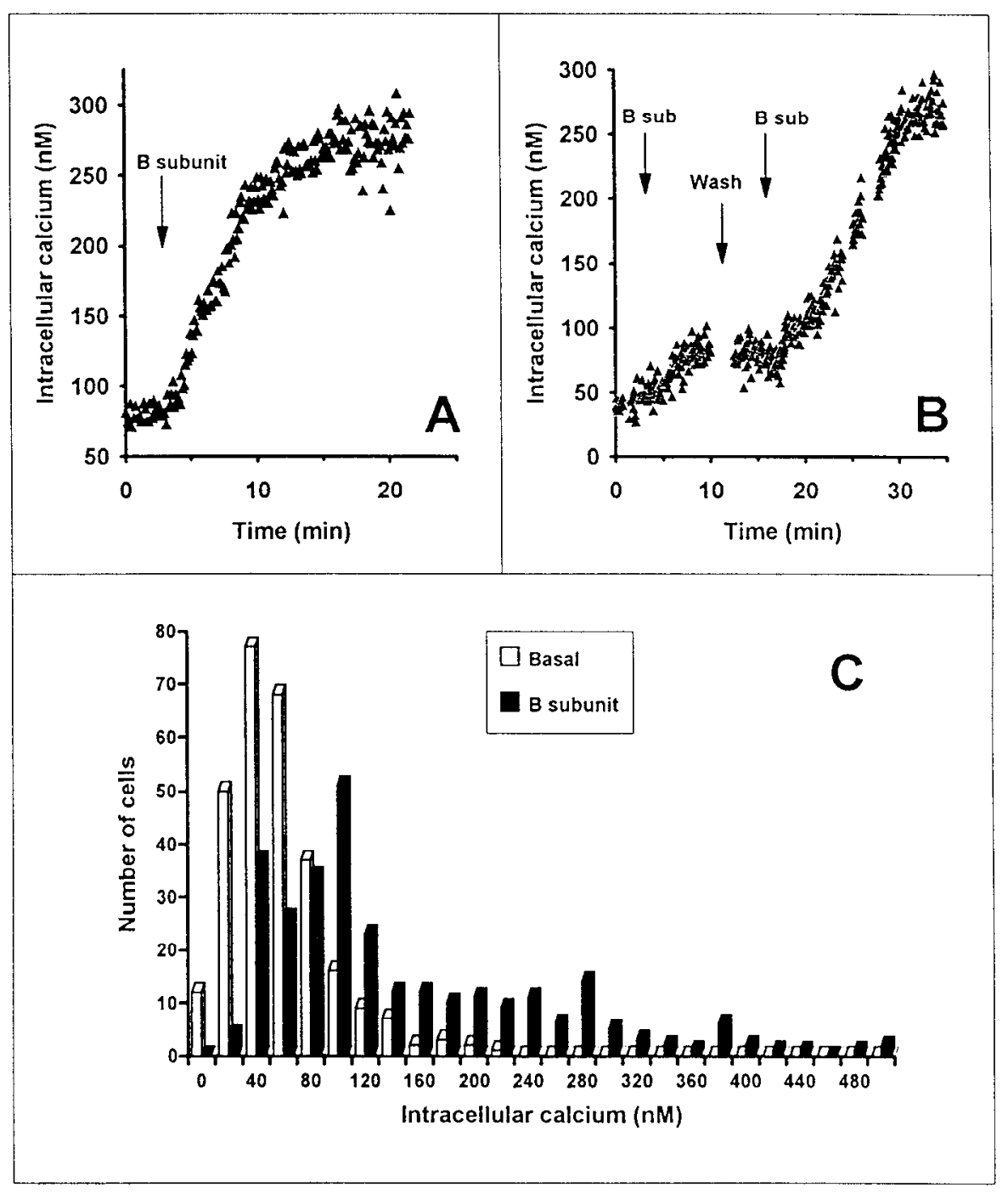

extracellular $\mathrm{Ca}^{2+}$ suggested the involvement of calcium influx in the $\mathrm{B}$ subunit-induced increase in $\left[\mathrm{Ca}^{2+}\right]_{i}$.

\section{$B$ subunit induces an influx of $\mathrm{Mn}^{2+}$}

To examine further the role of $\mathrm{Ca}^{2+}$ influx, the ability of $\mathrm{B}$ subunit to stimulate an influx of $\mathrm{Mn}^{2+}$ was studied. $\mathrm{Mn}^{2+}$ is a permeant ion for both voltage-dependent and receptor-operated $\mathrm{Ca}^{2+}$ channels (Merritt et al., 1989; Jacob, 1990; Rink, 1990). $\mathrm{Mn}^{2+}$ also quenches the fluorescence emission of fura- 2 and a decrease in fluorescence intensity in fura-2-loaded N18 cells can be used as an indicator of $\mathrm{Ca}^{2+}$ influx (Jacob, 1990; Rink, 1990). In $\mathrm{Ca}^{2+}$-free buffered saline, the presence of as little as $20 \mu \mathrm{M}$ $\mathrm{Mn}^{2+}$ often evoked detectable quenching, suggesting the existence of an active $\mathrm{Ca}^{2+}$ influx pathway in resting $\mathrm{N} 18$ cclls that leads to an apparently spontaneous influx of $\mathrm{Mn}^{2+}$, but the rate of this spontaneous influx was dependent upon the concentration of $\mathrm{Mn}^{2+}$. The rate of quenching observed for $\mathrm{Mn}^{2+}$ concentrations from 20 to $500 \mu \mathrm{M}$ was quite variable between N18 cells from different passages. To study the effect of $B$ subunit and other agents, $\mathrm{Mn}^{2+}$ was maintained at a concentration that did not elicit a substantial spontaneous influx (determined empirically in each experiment).

Addition of B subunit was found to substantially increase the rate of quenching in the presence of 20-250 $\mu \mathrm{M} \mathrm{Mn}^{2+}$, suggesting a stimulated increase in the rate of $\mathrm{Mn}^{2+}$ influx (Fig. 4A). This stimulation of $\mathrm{Mn}^{2+}$ influx occurred without a notable time lag after addition of $B$ subunit, and the rate of influx did not change while $\mathrm{B}$ subunit was present (Fig. $4 A$ ). After the $\mathrm{B}$ subunit and $\mathrm{Mn}^{2+}$ were washed out, readdition of $\mathrm{Mn}^{2+}$ did not result in a rate of influx comparable to that observed in the presence of $B$ subunit. However, readdition of $\mathrm{B}$ subunit stimulated $\mathrm{Mn}^{2+}$ influx, albeit at a lower rate than the initial application (Fig. $4 \mathrm{~A}$; see Fig. $6 B$ ).

$\mathrm{Ni}^{2+}$ was found to inhibit completely both spontaneous and B subunit-induced $\mathrm{Mn}^{2+}$ influx (Fig. 4B). $\mathrm{La}^{3+}$ also abolished both spontaneous and $\mathrm{B}$ subunit-induced $\mathrm{Mn}^{2+}$ influx $(200 \mu \mathrm{M}$ $\left.\mathrm{La}^{3+}, n=4\right)$. These results confirm that both the spontaneous and $\mathrm{B}$ subunit-induced $\mathrm{Mn}^{2+}$ influxes are due to $\mathrm{Mn}^{2+}$ permeation of a Ca ${ }^{2+}$ influx pathway, because both $\mathrm{Ni}^{2+}$ and $\mathrm{La}^{3+}$ are known to block $\mathrm{Ca}^{2+}$ entry into cells through any of the influx pathways utilized by $\mathrm{Mn}^{2+}$ (Lansman et al., 1986; Merritt et al., 1989; Rink, 1990).

\section{Depolarization or BayK8644 induces a $\mathrm{Mn}^{2+}$ influx and occludes the effect of $B$ subunit}

To induce depolarization of neuroblastoma N18 cells, the $\mathrm{K}^{+}$ concentration in the medium was increased from $5.4 \mathrm{~mm}$ to 72 $\mathrm{mM}$, with a concomitant decrease in $\mathrm{Na}^{+}$to maintain isoos- 


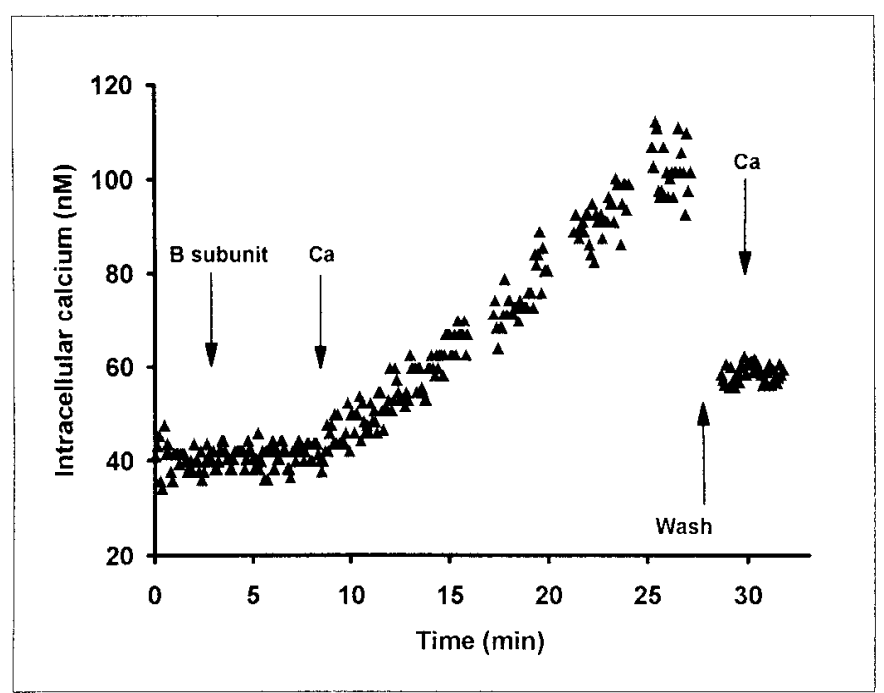

Figure 2. Effect of $\mathrm{Ca}^{2+}$-free medium on the B subunit-induced increase in $\left[\mathrm{Ca}^{2+}\right]_{i} \cdot\left[\mathrm{Ca}^{2+}\right]_{i}$ was monitored in neuroblastoma $\mathrm{N} 18$ cells initially in $\mathrm{Ca}^{2+}$-free saline. B subunit (180 nM) was added (at the time indicated by the first arrow), and subsequently $\mathrm{Ca}^{2+}$ was added to 1.8 mм. Then the cells were washed with $\mathrm{Ca}^{2+}$-free saline, and $\mathrm{Ca}^{2+}$ was again added to $1.8 \mathrm{~mm}$. The response of an individual cell from a representative experiment $(n=4)$ in which 19 of 19 cells responded similarly is depicted.

molarity. In the presence of $\mathrm{Mn}^{2+}$, this depolarization stimulated an increase in $\mathrm{Mn}^{2+}$ influx (Fig. 5A). After the onset of the depolarization-induced $\mathrm{Mn}^{2+}$ influx, addition of $\mathrm{B}$ subunit did not elicit further influx of $\mathrm{Mn}^{2+}$ (Fig. 5A). However, in the same population of cells, B subunit induced a substantial $\mathrm{Mn}^{2+}$ influx after washing to restore the normal, low- $\mathrm{K}^{+}, \mathrm{Ca}^{2+}$-free ionic conditions (Fig. $5 A$ ).

BayK8644, a dihydropyridine that stimulates L-type voltagedependent $\mathrm{Ca}^{2+}$ channel activity (Plummer et al., 1989), was also found to evoke $\mathrm{Mn}^{2+}$ influx (Fig. 5B). Similar to the effect of depolarization, B subunit was ineffective at stimulating additional $\mathrm{Mn}^{2+}$ influx in the presence of BayK8644 (Fig. 5B). Also similarly, B subunit induced $\mathrm{Mn}^{2+}$ influx in the same population of cells after washing (Fig. 5B).

\section{Niguldipine and nicardipine inhibit spontaneous and $B$ subunit-induced $\mathrm{Mn}^{2+}$ influx}

The effect of niguldipine and nicardipine, dihydropyridines that are antagonists of $\mathrm{L}$-type $\mathrm{Ca}^{2+}$ channel activity (Plummer et al., 1989), on $\mathrm{Mn}^{2+}$ influx was tested. Prior addition of either niguldipine (Fig. 6A) or nicardipine (data not shown) inhibited $\mathrm{B}$ subunit-induced $\mathrm{Mn}^{2+}$ influx. After washing, B subunit-induced $\mathrm{Mn}^{2+}$ influx was detectable (Fig. 6), indicating that the inhibition due to either niguldipine or nicardipine was reversible. These dihydropyridines were also inhibitory when added after onset of B subunit-induced $\mathrm{Mn}^{2+}$ influx (Fig. 7). Niguldipine and nicardipine similarly inhibited spontaneous $\mathrm{Mn}^{2+}$ influx (Fig. 8 ). In contrast, $\omega$-conotoxin $(1 \mu \mathrm{M})$, which is a selective inhibitor of $\mathrm{N}$-type voltage-dependent $\mathrm{Ca}^{2+}$ channels (Aosaki and Kasai, 1989; Plummer et al., 1989), had no effect on either spontaneous $(n=2)$ or B subunit-induced $\mathrm{Mn}^{2+}$ influx $(n=3)$, whether added before or after the $B$ subunit.

\section{Exogenous gangliosides inhibit $\mathrm{Mn}^{2+}$ influx}

The effect of several gangliosides on spontaneous $\mathrm{Mn}^{2+}$ influx was tested. At high concentrations $(>10 \mu \mathrm{M})$, either ganglioside

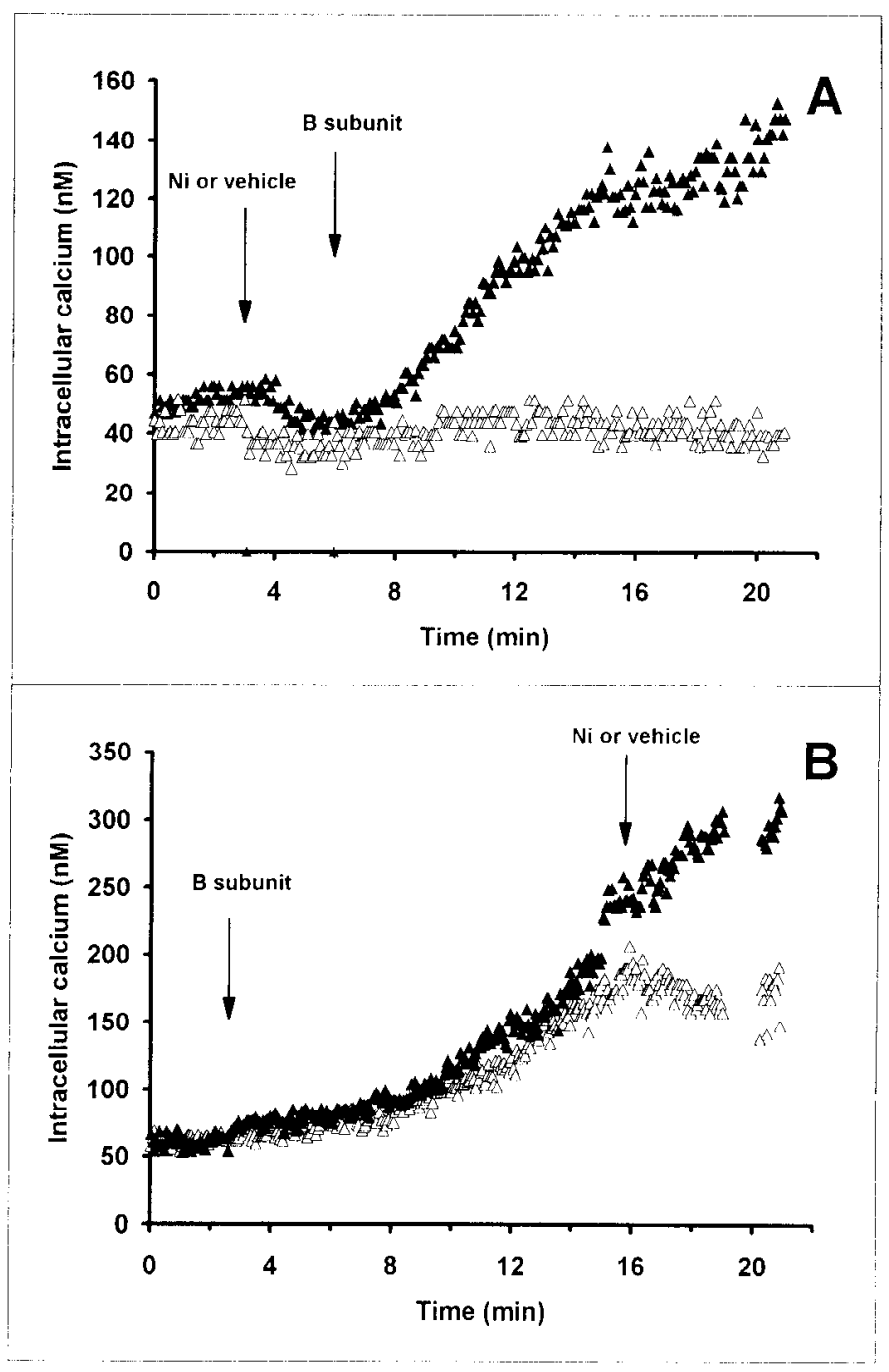

Figure 3. Effect of $\mathrm{Ni}^{2+}$ on the B subunit-induced increase in $\left[\mathrm{Ca}^{2+}\right]_{\text {. }}$. $A$, The effect of $\mathrm{B}$ subunit on $\left[\mathrm{Ca}^{2+}\right]_{i}$ was measured in the presence (open triangles) or absence (solid triangles) of $5 \mathrm{~mm} \mathrm{Ni}^{2+}$. For both conditions, calcium was present in the medium (cells were in phenol red/bicarbonate-free DMEM, which contains $\left.1.8 \mathrm{mM} \mathrm{Ca}^{2+}\right)$. At the time indicated by the first arrow, $\mathrm{Ni}^{2+}$ or vehicle (a volume of medium equal to the aliquot of $\mathrm{Ni}^{2+}$ stock solution) was added, after which B subunit (180 nM) was added to each. The responses of these individual cells are each from separate, but identically treated cell populations derived from the same passage and cultured simultaneously. In this representative experiment $(n=3)$, vehicle-treated cells displayed a $\mathrm{B}$ subunit-induced increase in $\left[\mathrm{Ca}^{2+}\right]_{i}$ in 15 of 15 cells; in the presence of $\mathrm{Ni}^{2+}, 0$ of 19 cells were responsive to $\mathrm{B}$ subunit. $B$, The effect of $\mathrm{Ni}^{2+}$ after the onset of the $B$ subunit-induced increase in $\left[\mathrm{Ca}^{2+}\right]_{i}$ was tested. $B$ subunit and subsequently $\mathrm{NiCl}_{2}(5 \mathrm{~mm})$ or vehicle was added. The responses of these individual cells are from a representative experiment $(n=5)$ in which the $B$ subunit-induced response was similarly blocked in 30 of 30 cells.

GM1 or GM3 completely inhibited spontaneous $\mathrm{Mn}^{2+}$ influx (Fig. 9A,B). As little as $200 \mathrm{nM}$ GM1 induced detectable inhibition, and GM1 at $>2 \mu \mathrm{M}$ gave complete inhibition (Fig. $9 A$ ). In contrast, $10 \mu \mathrm{M}$ GM3 was required for complete inhibition (Fig. 9B) and globoside, even at concentrations as high as 10 $\mu \mathrm{M}$, did not significantly decrease the rate of quenching (Fig. 9C). As expected, GMl also inhibited $\mathrm{Mn}^{2+}$ influx induced by the B subunit when B subunit and GMI were mixed prior to addition to N18 cells (data not shown). 


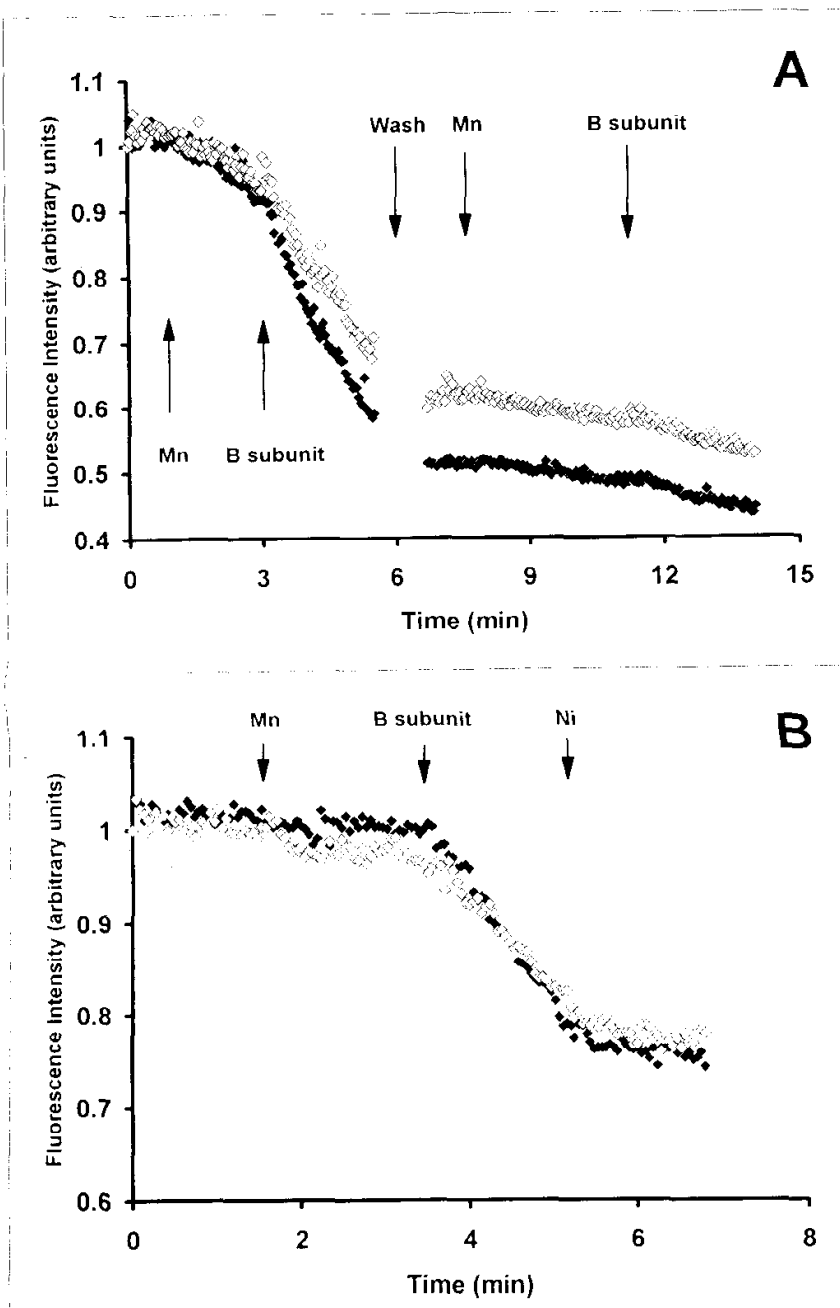

Figure 4. B subunit stimulated influx of $\mathrm{Mn}^{2+} . A$, The average intensity of fluorescence emission due to excitation at $380 \mathrm{~nm}$ (solid diamonds) or $334 \mathrm{~nm}$ (open diamonds) is depicted for a population of neuroblastoma $\mathrm{N} 18$ cells in $\mathrm{Ca}^{2+}$-free saline. $\mathrm{MnCl}_{2}(200 \mu \mathrm{M})$ was added at the time indicated by the first arrow, followed by addition of $\mathrm{B}$ subunit ( 180 nM). Following a wash with $\mathrm{Ca}^{2+}$-free saline, $\mathrm{MnCl}_{2}(200 \mu \mathrm{M})$ and $\mathrm{B}$ subunit $(180 \mathrm{nM})$ were added again in succession. In this representative experiment ( $n=3$ for testing the effect of repeated exposure to B subunit), B subunit stimulated an increased rate of quenching in 25 of 27 cells initially and in 26 of 27 cells after the wash. For 26 of 27 cells the initial rate of quenching was greater than the subsequent response. $B$, The average fluorescence due to excitation at $380 \mathrm{~nm}$ (solid diamonds) or $334 \mathrm{~nm}$ (open diamonds) is depicted for a population of N18 cells in $\mathrm{Ca}^{2+}$-free saline after successive addition of $\mathrm{MnCl}_{2}(200 \mu \mathrm{M})$, B subunit ( $360 \mathrm{~nm}$ ), and $\mathrm{NiCl}_{2}(2 \mathrm{~mm})$. In this representative experiment ( $n$ $=6$ for $2-5 \mathrm{mM} \mathrm{Ni}^{2+}$ ), 33 of 33 cells responded to $\mathrm{B}$ subunit and the subsequent addition of $\mathrm{Ni}^{2}$ completely inhibited the increased rate of quenching in all cells.

\section{Discussion}

\section{$B$ subunit binding to endogenous $G M 1$ stimulates $L$-type $\mathrm{Ca}^{2+}$ channels}

In this article we have found that the B subunit of cholera toxin, which binds exclusively to ganglioside GM1, induced a sustained increase of $\left[\mathrm{Ca}^{2+}\right]_{i}$ in N18 mouse neuroblastoma cells. The dependence of this increase on the presence of extracellular $\mathrm{Ca}^{2+}$, the inhibition by $\mathrm{Ni}^{2+}$, and the induction of $\mathrm{Mn}^{2+}$ influx all suggest that extracellular $\mathrm{Ca}^{2+}$ influx is the source of the $\mathrm{B}$

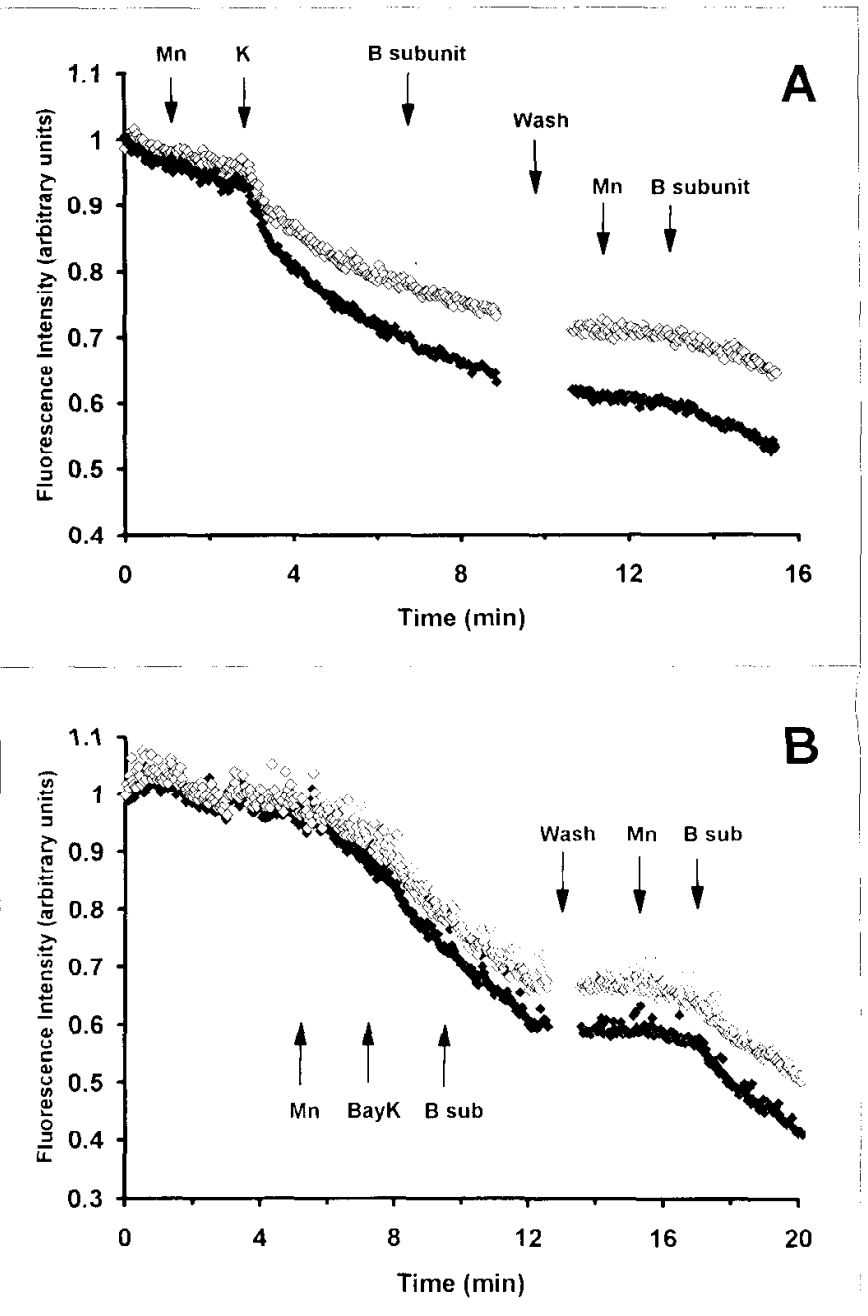

Figure 5. Effect of depolarization or BayK 8644 on B subunit-induced $\mathrm{Mn}^{2+}$ influx. $A$, The average fluorescence intensity due to excitation at $380 \mathrm{~nm}$ (solid diamonds) or $334 \mathrm{~nm}$ (open diamonds) is depicted for a population of ncuroblastoma $\mathrm{N} 18$ cells in $\mathrm{Ca}^{2+}$-free saline after successive addition of $\mathrm{MnCl}_{2}(200 \mu \mathrm{M}), \mathrm{KCl}$ (increased from $5.4 \mathrm{~mm}$ to 72 $\mathrm{mM}$ with a concomitant decrease in $\mathrm{NaCl}$ to maintain isotonicity), and $B$ subunit (180 nM). Washing with $\mathrm{Ca}^{2+}$-free saline restored normal ionic conditions, after which $\mathrm{MnCl}_{2}(200 \mu \mathrm{M})$ and $\mathrm{B}$ subunit (180 nM) were again added in succession. In this representative experiment $(n=$ 5 ), elevated $\mathrm{K}^{+}$stimulated an increased rate of quenching in 15 of 15 cells and subsequent addition of $B$ subunit stimulated a detectable increase in 2 of 15 cells. After washing, 14 of 15 cells responded to $B$ subunit. $B$, The average fluorescence intensity due to excitation at 380 $\mathrm{nm}$ (solid diamonds) or $334 \mathrm{~nm}$ (open diamonds) is depicted for a population of $\mathrm{N} 18$ cells in $\mathrm{Ca}^{2+}$-free saline after successive addition of $\mathrm{MnCl}_{2}(100 \mu \mathrm{M})$, BayK8644 (1 $\left.\mu \mathrm{M}\right)$, and B subunit (180 nM). Subsequent to a wash with $\mathrm{Ca}^{2+}$-free saline, $\mathrm{MnCl}_{2}(100 \mu \mathrm{M})$ and $\mathrm{B}$ subunit (180 $\mathrm{nM}$ ) were added in succession. In separate experiments, no effect of the vehicle for BayK $8644[0.1 \%$ ethanol $(\mathrm{v} / \mathrm{v})$ in calcium-free saline] was observed. In this representative experiment $(n=3)$, BayK8644 stimulated an increased rate of quenching in 17 of 17 cells and subsequent addition of $B$ subunit stimulated a detectable increase in 4 of 17 cells. After washing, 17 of 17 cells responded to $B$ subunit.

subunit-stimulated calcium increase. To identify specifically the $\mathrm{Ca}^{2+}$ influx pathway involved, $\mathrm{Mn}^{2+}$ influx was studied in detail. $\mathrm{Mn}^{2+}$ has several characteristics that make it highly suitable for this purpose. First, it quenches fura-2 fluorescence such that its entry into the cytoplasm can readily be detected. Second, $\mathrm{Mn}^{2+}$ 


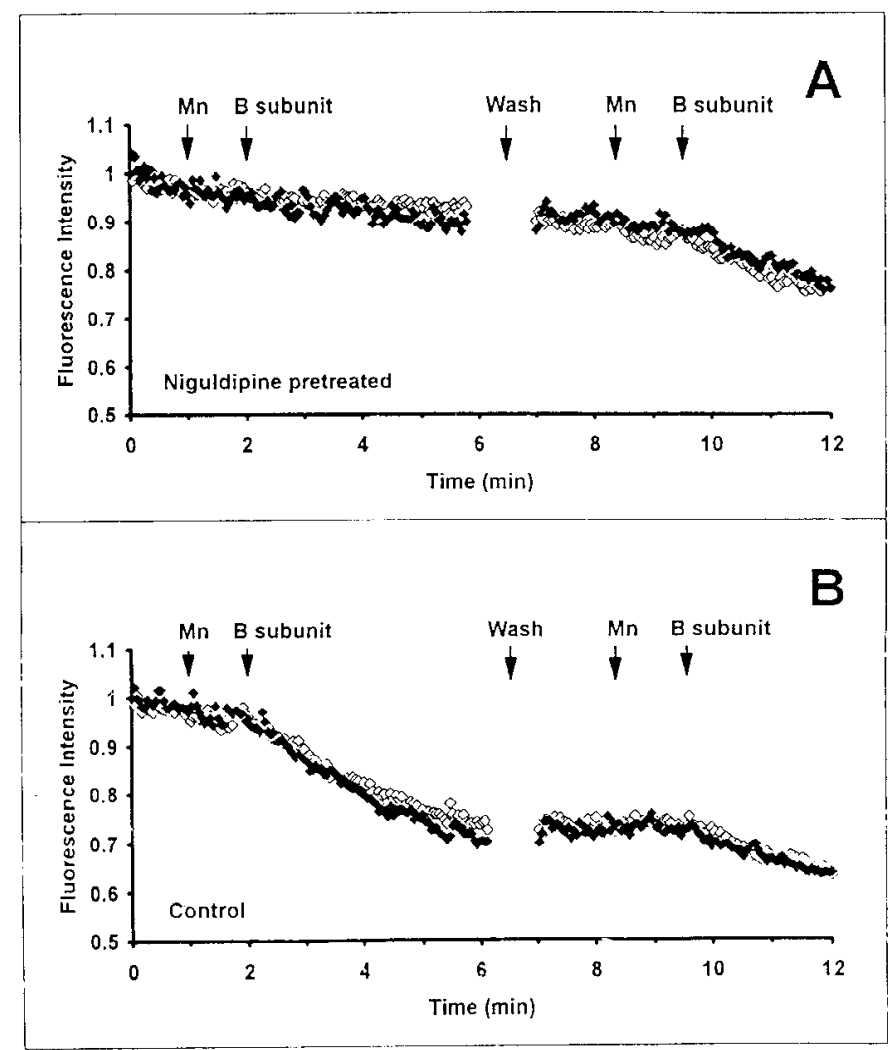

Figure 6. Lack of effect of $\mathrm{B}$ subunit on $\mathrm{Mn}^{2+}$ influx in the presence of dihydropyridine antagonist. Cells were pretreated for $5 \mathrm{~min}$ with niguldipine $(A ; 5 \mu \mathrm{M})$, or vehicle $[B ; 0.25 \%$ dimethyl sulfoxide $(\mathrm{v} / \mathrm{v})$ in $\mathrm{Ca}^{2+}$-free saline], and then, in the continued presence of dihydropyridine (or vehicle), $\mathrm{MnCl}_{2}(50 \mu \mathrm{M})$ and B subunit $(360 \mathrm{nM})$ were added in succession. For this representative experiment $(n=3)$, the average fluorescence due to excitation at $380 \mathrm{~nm}$ (solid diamonds) or $334 \mathrm{~nm}$ (open diamonds) is depicted for separate cell populations from the same passage (cultured simultaneously). In $A, 10$ of 32 cells were detectably responsive to $B$ subunit in the presence of niguldipinc; however, this responsiveness did not significantly increase average rate of quenching. In $B, 37$ of 37 of the untreated cells responded to $B$ subunit before and after the wash. is a permeant ion for either voltage-dependent (Lansman et al., 1986) or receptor-operated calcium channels (Merritt et al., 1989), but cannot substitute for $\mathrm{Ca}^{2+}$ in $\mathrm{Na}^{+} / \mathrm{Ca}^{2+}$ exchange (Smith et al., 1987; Haworth et al., 1989). Therefore, $\mathrm{Mn}^{2+}$ entry into cells can only occur through calcium channels. Finally, cells do not contain intracellular stores of $\mathrm{Mn}^{2+}$, and channels that refill intracellular calcium stores are impermeable to $\mathrm{Mn}^{2+}(\mathrm{Ja}-$ cob, 1990; Rink, 1990). Thus, quenching of intracellular fura-2 fluorescence intensity is an unambiguous indication of $\mathrm{Mn}^{2+}$ entry.

The lack of effect of B subunit after the onset of depolarization-induced $\mathrm{Mn}^{2+}$ influx suggested involvement of a voltagedependent $\mathrm{Ca}^{2+}$ channel. BayK8644, an activator of L-type voltage-dependent $\mathrm{Ca}^{2+}$ channels, also induced $\mathrm{Mn}^{2+}$ influx and produced a similar occlusion of the response to the $B$ subunit. The ability of niguldipine or nicardipine, dihydropyridines that block L-type $\mathrm{Ca}^{2+}$ channels (Plummer et al., 1989), to inhibit completely the $\mathrm{B}$ subunit-induced influx further corroborated the involvement of L-type channels. In addition, dihydropyridinc-mediated inhibition of spontancous $\mathrm{Mn}^{2+}$ influx implicd that $\mathrm{Ca}^{2+}$ influx that occurs in unstimulated N18 cells is almost entirely due to L-type channel activity. We conclude that the $\mathrm{B}$ subunit-induced increase in $\left[\mathrm{Ca}^{2+}\right]_{i}$ is likely a result of increased $\mathrm{Ca}^{2+}$ influx through L-type $\mathrm{Ca}^{2+}$ channels.

These effects of the $\mathrm{B}$ subunit imply a role for endogenous GMl in the regulation of L-type $\mathrm{Ca}^{2+}$ channel activity. The ability of B subunit to bind to ganglioside GM1 in the outer leaflet of cell membranes with high affinity and selectivity relative to other gangliosides is well established (Fishman, 1990). Much of the seminal work in this area was done in N18 cells, which are known to be enriched in GMl similar to other neuronal cell types (Fishman and Atikkan, 1980; Miller-Podraza et al., 1982). B subunit has been used previously as a tool to implicate endogenous GM1 in the regulation of $\mathrm{Ca}^{2+}$ homeostasis in other cell types (Dixon et al., 1987; Spiegel and Panagiotopoulos, 1988; Mulhern et al., 1989; Milani et al., 1992). We previously found that the $B$ subunit induced a rapid increase in intracellular free calcium mediated by a net influx in rat thymocytes (Dixon et al., 1987) and in quiescent 3 T 3 fibroblasts
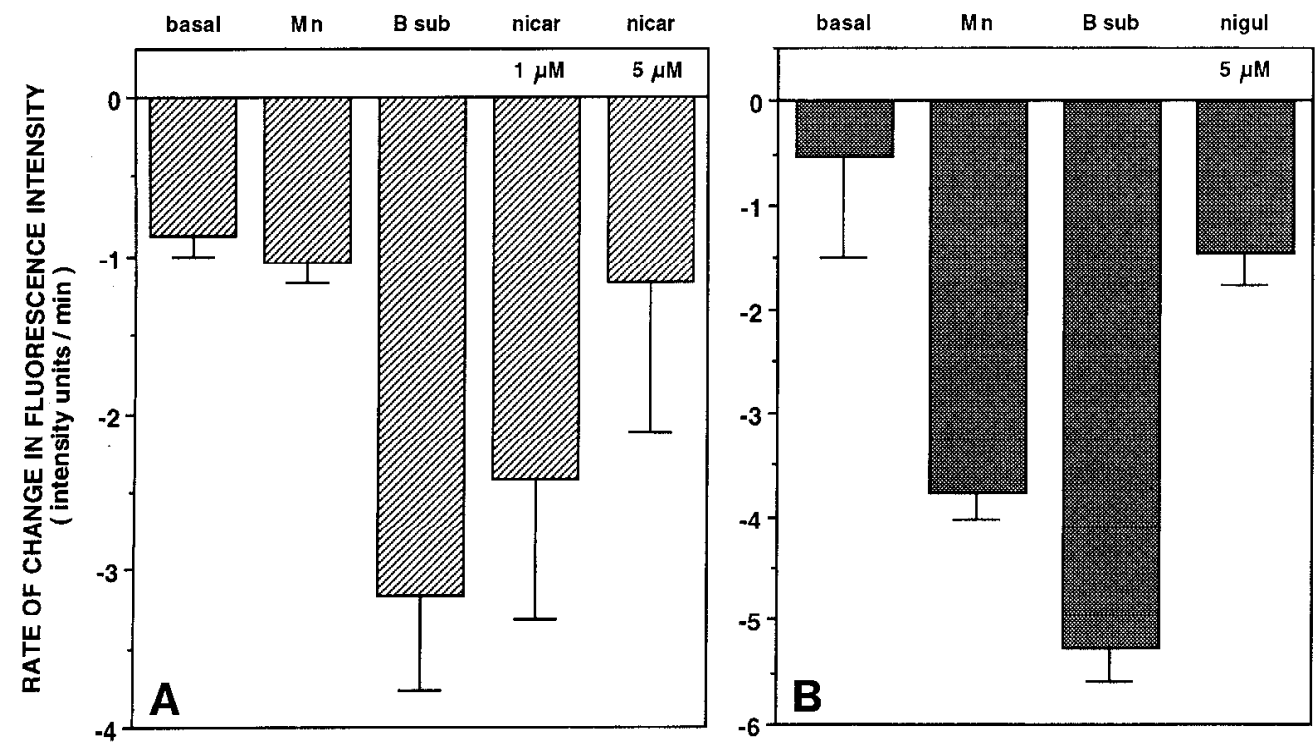

Figure 7. The effect of dihydropyridines after the onset of B subunit-induced $\mathrm{Mn}^{2+}$ influx. The effect of nicardipine $(A ; 1$ and $5 \mu \mathrm{M})$ or niguldipine $(B ; 5 \mu \mathrm{M})$ tested after the successive addition of $\mathrm{MnCl}_{2}(50 \mu \mathrm{M})$ and $\mathrm{B}$ subunit $(360 \mathrm{nM})$. The rate of change of fluorescence intensity as a function of time was determined over a period of $90 \mathrm{sec}$ immediately prior to the successive addition of each compound. In these representative experiments $(n=5$ for nicardipine; $n=8$ for niguldipine), the average rate of change of fluorescence intensity due to excitation at $380 \mathrm{~nm}$ is depicted in each for a population of cells. 


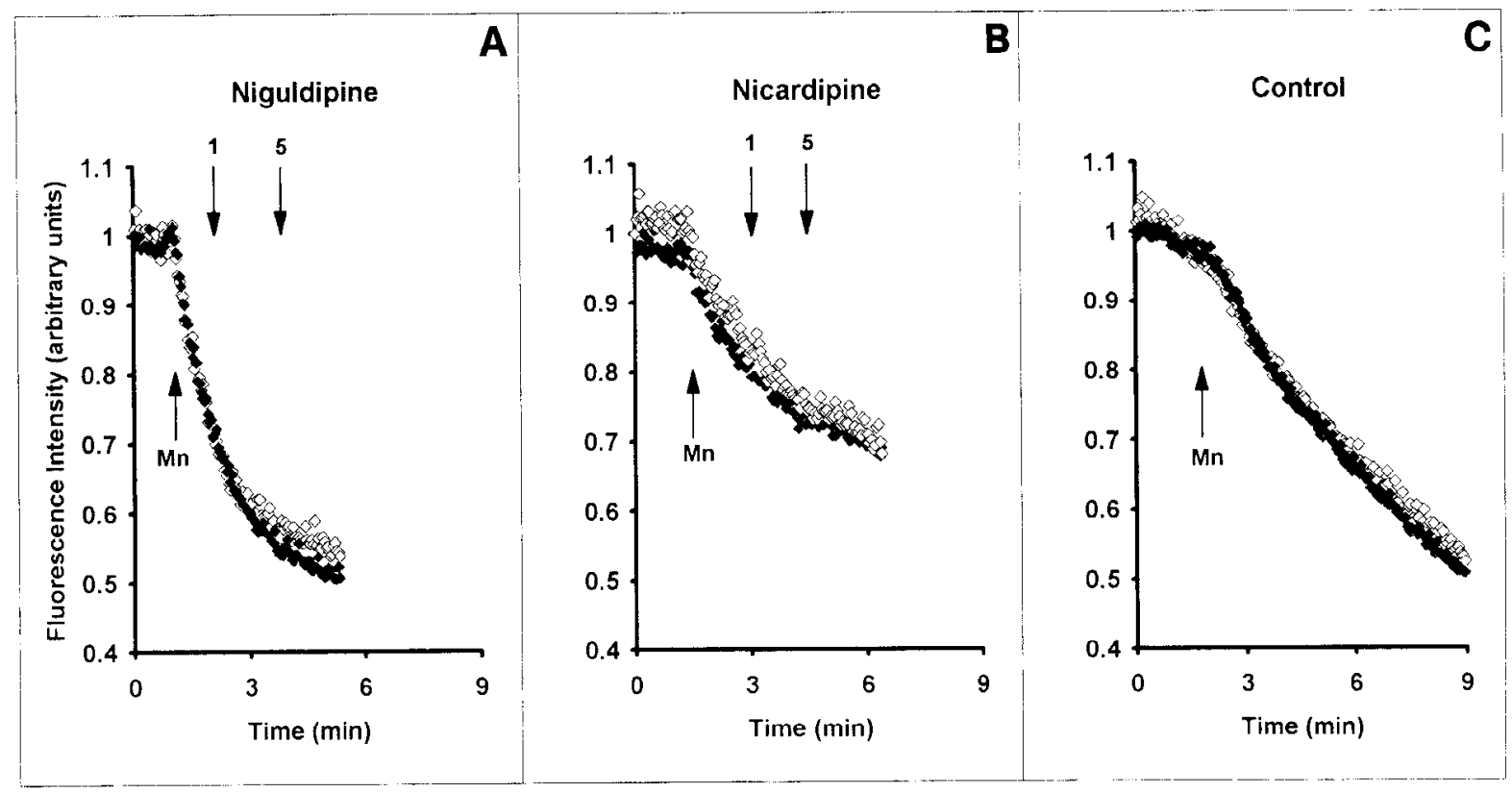

Figure 8. Effect of dihydropyridines on the spontaneous $\mathrm{Mn}^{2+}$ influx. The effect of niguldipine $(A)$ or nicardipine $(B)$ was tested on the spontaneous influx of $\mathrm{Mn}^{2+}$ in the presence of $200 \mu \mathrm{M}$ extracellular $\mathrm{MnCl}_{2}$. In each experiment $\mathrm{MnCl}_{2}$ was added, followed by $1 \mu \mathrm{M}$ concentrations of the respective dihydropyridine, which was subsequently increased to $5 \mu \mathrm{M}$ at the times indicated by the arrows. For these representative experiments ( $n=9$ for nicardipine; $n=4$ for niguldipine), the average fluorescence due to excitation at $380 \mathrm{~nm}$ (solid diamonds) or $334 \mathrm{~nm}$ (open diamonds) is depicted for a cell population of the same passage. In $A, 1 \mu \mathrm{M}$ niguldipine inhibited the spontaneous influx in 27 of 27 cells; $5 \mu \mathrm{M}$ niguldipine was more inhibitory than $1 \mu \mathrm{M}$ in all the cells, leading to nearly complete inhibition [a $91 \pm 12 \%( \pm \mathrm{SEM})$ decrease in the rate of quenching relative to $\mathrm{Mn}^{2+}$ alone]. In $B, 5 \mu \mathrm{M}$ nicardipine inhibited the spontaneous influx in 30 of 33 cells.

(Spiegel and Panagiotopoulos, 1988). A similar effect has also been observed in astrocytes (Gabellini et al., 1991) and in dissociated sensory neurons from chick embryo (Milani et al., 1992). The stimulation of L-type calcium channels presented here provides the first identification of a specific endogenous GMI-mediated pathway that could potentially account for the observed $B$ subunit-induced changes in $\mathrm{Ca}^{2+}$ homeostasis.

Endogenous GMI may act as a constitutive inhibitor of L-type $\mathrm{Ca}^{2+}$ channel activity

Although the B subunit is known to exert effects on cellular functions through binding to endogenous ganglioside GM1, precisely how this binding leads to the observed calcium changes in cells has nut been determined previously. The ability of exogenous GM1 to inhibit the same pathway stimulated by the B subunit provides insight for a possible mechanism. The effect of exogenous GM1 suggests that endogenous GM1 could normally play a role as a constitutive negative modulator of L-type $\mathrm{Ca}^{2+}$ channels. Binding of the B subunit could prevent endogenous GMl from interacting with L-type channels. We suggest that the B subunit-mediated sequestration of endogenous GM 1 leads to disinhibition of L-type $\mathrm{Ca}^{2+}$ channels, and the resulting $\mathrm{Ca}^{2+}$ influx is responsible for the increase in $\left[\mathrm{Ca}^{2+}\right]_{\text {, }}$.

Some characteristics of this endogenous GMl-mediated inhibition are discernible. In unstimulated $\mathrm{N} 18$ cells, L-type channels must only be partially closed or inactivated, because additional GM1 promoted further inhibition of the L-type channel activity. Furthermore, endogenous GMl-modulated channels retain voltage sensitivity, since B subunit was without effect when N18 cells were depolarized. Channcls normally inhibited by GM1, and therefore responsive to sequestration of GM1, must have undergone depolarization-induced activation. Consistent with this proposal, Frieder and Rapport found that an- tibodies to GM1 enhanced GABA release from rat brain slices in a calcium-dependent manner, indicating that GM1 may act as a constitutive inhibitor of voltage-dependent calcium channels (Frieder and Rapport, 1981, 1987). More recently, Slomiany and colleagues reported that exogenous GM1 inhibited reconstituted gastric mucosal dihydropyridine-sensitive calcium channel activity with a maximum inhibitory effect at relatively low concentrations of ganglioside GM1 (10-15 nM) (Slomiany et al., 1992). Furthermore, GM1 was an antagonist for specific dihydropyridine binding to this reconstituted channel, indicating the extracellular orientation of calcium channel domains for GMl (Slomiany et al., 1992). Recently, dihydropyridine receptor sites have been localized to the extracellular end of the interface between domains III and IV of the $\alpha 1$ subunit of L-type calcium channels (Catterall and Striessnig, 1992). Since ganglioside GM1 is located mainly on the outer surface of the plasma membrane bilayer, it is a reasonable speculation that endogenous GM1-mediated inhibition of L-type channels may occur by interaction with the dihydropyridine binding site on the L-type channel or on an overlapping site and ganglioside GM1 may function as an "endogenous dihydropyridine."

In stark contrast to this proposal that GM1 acts as an inhibitor of L-type channels, others have suggested that ganglioside GM1 can stimulate rather than inhibit calcium influx. Roisen and colleagues have demonstrated that GM1-induced neuritogenesis in Neuro-2a neuroblastoma cells was accompanied by an increase in cytoplasmic free calcium (Spoerri et al., 1990). Similarly, it has been shown that bovine brain gangliosides elicited an increase in both calcium influx and efflux in Neuro-2a cells (Wu et al., 1990). Recently, Hilbush and Levine have concluded that exogenous GM1 acts to potentiate the activity of L-type channels in PCI 2 cells (Hilbush and Levine, 1992). They found that exogenous GM1 increased the depolarization- or bradyki- 


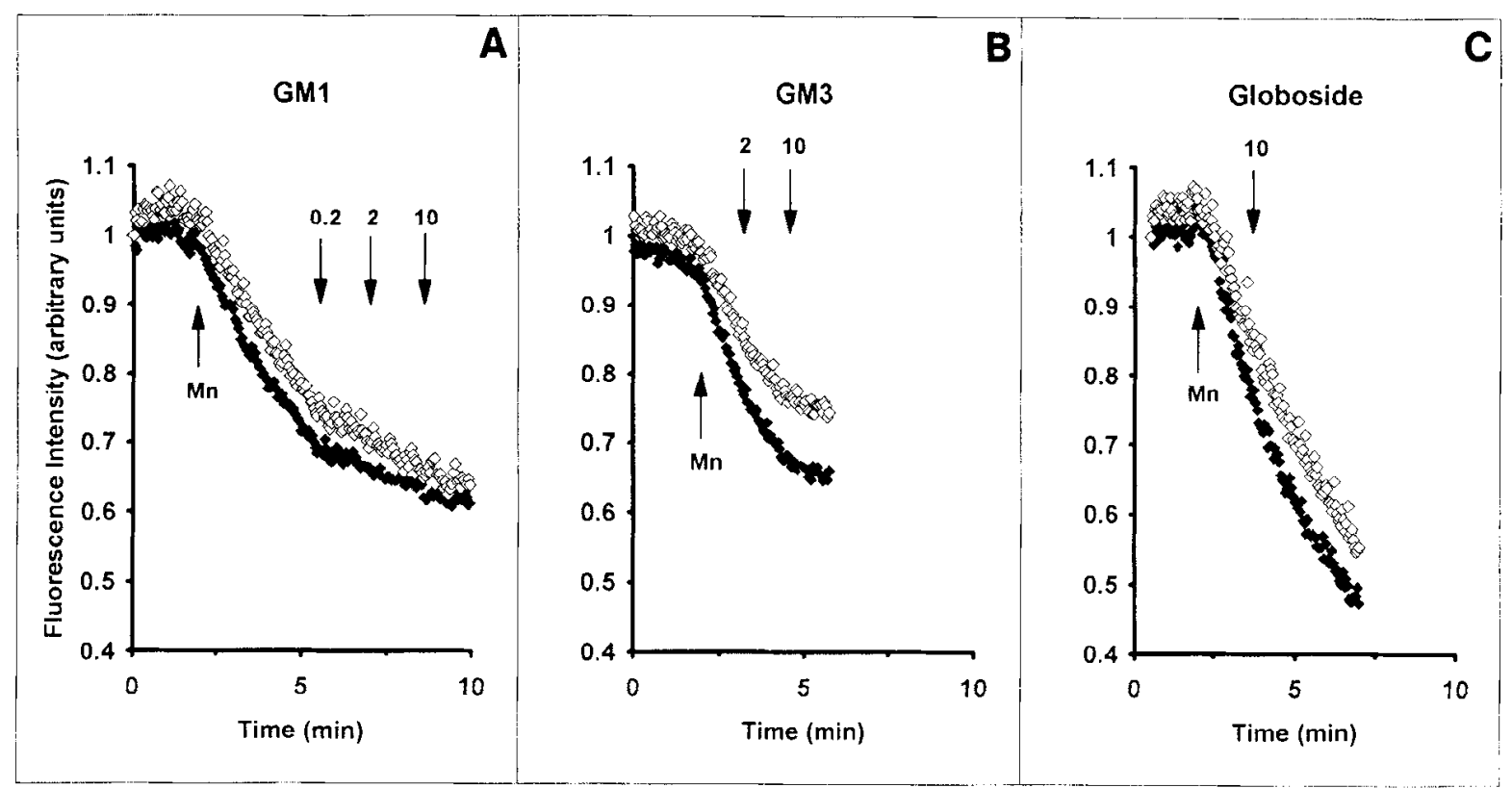

Figure 9. Effect of gangliosides on the spontaneous $\mathrm{Mn}^{2+}$ influx. The effect of ganglioside GM1 $(A)$, ganglioside GM3 (B), or globoside $(C)$ was tested on the spontaneous influx of $\mathrm{Mn}^{2+}$ in the presence of $100 \mu \mathrm{M}$ extracellular $\mathrm{MnCl}_{2}$. In $A$, after addition of $\mathrm{MnCl}_{2}, 200 \mathrm{nM} \mathrm{GM} 1$ was added, then increased to $2 \mu \mathrm{M}$, and then $10 \mu \mathrm{M}$, successively at the times indicated by the arrows. In $B, 2 \mu \mathrm{M}$ GM 3 was added and then increased to 10 $\mu \mathrm{M}$. In $C, 10 \mu \mathrm{M}$ globoside was after addition of $\mathrm{MnCl}_{2}$. For this representative experiment $(n=3)$, the average fluorescence due to excitation at $380 \mathrm{~nm}$ (solid diamonds) or $334 \mathrm{~nm}$ (open diamonds) is depicted.

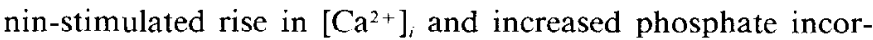
poration into a specific substrate of $\mathrm{Ca}^{2+} /$ calmodulin-dependent protein kinase. Removal of extracellular $\mathrm{Ca}^{2+}$ or addition of the dihydropyridine nitrendipine abolished these effects, implicating L-type channel activity (Hilbush and Levine, 1992). Also, it was recently reported that exogenous GM1 potentiated neural cell adhesion molecule- or N-cadherin-induced neuritogenesis in PCI 2 cells (Doherty et al., 1992), a process previously shown to be dependent on L-type and N-type calcium channel activity (Doherty et al., 1991).

A notable difference between our studies, which found stimulatory effects, and those that described inhibitory effects of ganglioside GMl is that the apparent $\mathrm{GMl}$-mediated potentiation of L-type calcium channel activity in PC12 cells was obscrved at higher concentrations (10-100 $\mu \mathrm{M})$ than were found to effectively inhibit L-type channels in N18 cells (as little as $200 \mathrm{nM}$ ). Thus, ganglioside GM1 may have a dual action on calcium transport similar to the known bimodal action of dihydropyridines. Although it is now accepted that dihydropyridines generally have high affinity for the inactivated state of the calcium channel and low affinity for the other states (closed, open), they have high affinity for the open state in smooth muscle cells (Spedding and Paoletti, 1992). Similarly, ryanodine has been shown to open calcium-induced calcium release channels at low concentrations and to block them at high concentrations (Pessah and Zimanyi, 1991). Furthermore, different cell types could have different forms of L-type calcium channels existing in multiple states. Further studies are necessary to distinguish between these possibilities.

\section{Role of ganglioside GM1-mediated calcium changes in neuronal differentiation}

Our previous findings that the B subunit stimulated neuritogenesis in N18 cells implicated endogenous GM1 in the process of differentiation (Masco et al., 1991). More recently, the B subunit was found to induce neurite branching in primary cultures of chick dorsal root ganglion neurons, an effect that was enhanced after preincubation with exogenous GM1 (Milani et al., 1992). The B subunit also stimulated an increase in $\left[\mathrm{Ca}^{2+}\right]$ in these cells. The magnitude of the induced increase in $\left[\mathrm{Ca}^{2+}\right]$ in DRG neurons was comparable to the response in $\mathrm{N} 18$ cells, and also similarly represented a steady-state change in $\left[\mathrm{Ca}^{2+}\right]_{i}$. However, dihydropyridines did not block the response in DRG neurons, despite a similar dependence on the presence of extracellular $\mathrm{Ca}^{2+}$. Since dihydropyridines also failed to prevent the depolarization-induced increase in $\left[\mathrm{Ca}^{2+}\right]_{i}$ in DRG neurons, it is likely that these cells may not express L-type channel activity.

There is overwhelning evidence that calcium influx through the plasma membrane influences neurite initiation, growth cone motility, and neuronal survival (Miller, 1987; Kater et al., 1988; Tsien et al., 1988; Kater and Mills, 1991). Kater and co-workers have suggested that there is a narrow, optimal level of cytosolic free calcium, below or above which these processes are inhibited (Mattson et al., 1988; Kater and Mills, 1991). Furthermore, L-type calcium channels have been shown recently to play an important role in neurite initiation in cultured chick embryo brain neurons and in N1E-115 neuroblastoma cells (Audesirk et al., 1990) and to promote neuron survival (Collins et al., 1991). Thus, the ability of the B subunit to regulate L-type calcium channels through its binding to endogenous ganglioside GM1 may be related to its effect on neuritogenesis in N18 cells (Masco et al., 1991) and its ability to increase survival of neurons. Furthermore, the modulation of L-type calcium channels by endogenous ganglioside GM1 may have important implications not only for its role in neural development, differentiation, and regeneration but also for its potential function in the electrical excitability of neurons. 


\section{References}

Aosaki T, Kasai H (1989) Characterization of two kinds of highvoltage-activated Ca-channel currents in chick sensory neurons. Differential sensitivity to dihydropyridincs and omcga-conotoxin. Pfluegers Arch 414:150-156.

Argentino C, Sacchetti M, Toni D, Savoini G, D'Acangelo E, Erminio F, Federico F, Ferro F, Gallai V, Gambi D, Mamoli A, Ottonello GA, ZPonari O, Rebucci G, Semin U, Fieschi C (1989) GMI ganglioside therapy in acute ischemic stroke. Stroke 20:1143-1149.

Audesirk G, Audesirk T, Fergusoon C, Lomme M, Shugarts D, Rosack J, Caracciolo P, Gisi T, Nichols P (1990) L-type calcium channels may regulate neurite initiation in cultured chick embryo brain neurons and N1E-1 15 neuroblastoma cells. Dev Brain Res 55:109-120.

Benfenati F, Fuxe K, Agnati LF (1991) Ganglioside GM1 modulation of calcium/calmodulin-dependent protein kinase II activity and autophosphorylation. Neurochem Int 19:271-279.

Buckley NE, Matyas GR, Spiegel S (1990) The bimodal growth response of Swiss 3T3 cells to the B subunit of cholcra toxin is independent of the density of its receptor, ganglioside GM1. Exp Cell Res 189:13-21.

Catterall D, Striessnig J (1992) Receptor sites for $\mathrm{Ca}^{2+}$ channel antagonists. Trends Pharmacol Sci 13:256-262.

Cimino M, Benfenati F, Farabegoli C, Cattabeni F, Fuxe K, Agnati LF, Toffano G (1987) Differential effect of ganglioside GM1 on rat brain phosphoproteins: potentiation and inhibition of protein phosphorylation regulated by calcium calmodulin and calcium phospholipiddependent protein kinases. Acta Physiol Scand 130:317-325.

Collins F, Schmidt MF, Guthrie PB, Kater SB (1991) Sustained increase in intracellular calcium promotes neuronal survival. $\mathrm{J}$ Neurosci $11: 2582-2587$.

De Erausquin BA, Manev H, Guidotti A, Costa E, Brooker G (1990) Gangliosides normalize distorted single-cell intracellular free $\mathrm{Ca}^{2+}$ dynamics after toxic doses of glutamate in cerebellar granule cells. Proc Natl Acad Sci USA 87:8017-8021.

Dixon SJ, Stewart D, Grinstein S, Spiegel S (1987) Transmembrane signaling by the B subunit of cholera toxin: increased cytoplasmic free calcium in rat lymphocytes. J Cell Biol 105:1153-1161.

Doherty P, Ashton SV, Moore SE, Walsh FS (1991) Morphoregulatory activities of NCAM and N-cadherin can be accounted for by G-protein-dependent activation of $\mathrm{L}$-type and $\mathrm{N}$-type neuronal $\mathrm{Ca}^{2+}$ channels. Cell 67:21-33.

Doherty P, Ashton SV, Skaper SD, Leon A, Walsh FS (1992) Ganglioside modulation of neural cell adhesion molecule and $\mathrm{N}$-cadherindependent neurite outgrowth. J Cell Biol 117:1093-1099.

Fishman PH (1990) Mechanism of action of cholera toxin. In: ADPribosylating toxins and $G$ proteins: insights into signal transduction (Moss J, Vaughan M, eds), pp 127-140. Washington, DC: American Society for Microbiology.

Fishman PH, Atikkan EE (1980) Mechanism of action cholera toxin: effect of receptor density and multivalent binding on activation of adenylate cyclase. J Membr Biol 54:51-60.

Frieder B, Rapport MM (1981) Enhancement of depolarization-induced release of GABA from brain slices by antibodies to gangliosides. J Neurochem 37:634-639.

Frieder B, Rapport MM (1987) The effect of antibodies to gangliosides on $\mathrm{Ca}^{2+}$ channel-linked release of gamma-aminobutyric acid in rat brain slices. J Neurochem 48:1048-1052.

Gabellini N, Facci L, Milani D, Negro A, Callegaro L, Skaper SD, Leon A (1991) Differences in induction of c-fos transcription by cholera toxin-derived cyclic AMP and $\mathrm{Ca}^{3+}$ signals in astrocytes and 3T3 fibroblasts. Exp Cell Res 194:210-217.

Geisler FH, Dorsey FC, Coleman WP (1991) Recovery of motor function after spinal cord injury - a randomized placebo controlled trial with GMl ganglioside. New Engl J Med 324:1829-1838.

Goldenring JR, Otis LC, Yu RK, DeLorenzo RJ (1985) Calcium ganglioside-dependent protein kinase activity in rat brain membrane. J Neurochem 44:1229-1234.

Hakomori S (1990) Bifunctional role of glycosphingolipids. Modulators for transmembrane signaling and mediators for cellular interactions. J Biol Chem 265:18713-18716.

Haworth RA, Goknur AB, Berkoff HA (1989) Measurement of Ca channel activity of isolated adult rat heart cells using ${ }^{54} \mathrm{Mn}$. Arch Biochem Biophys 268:594-604.

Hilbush BS, Levinc JM (1991) Stimulation of a $\mathrm{Ca}^{2+}$-dependent pro- tein kinase by GM1 ganglioside in nerve growth factor-treated PC12 cells. Proc Natl Acad Sci USA 88:5616-5620.

Hilbush BS, Levine JM (1992) Modulation of a $\mathrm{Ca}^{2+}$ signaling pathway by GM1 ganglioside in PC12 cells. J Biol Chem 267:24789-24795.

Jacob R (1990) Agonist-stimulated divalent cation entry into single cultured human umbilical vein endothelial cells. J Physiol (Lond) 421:55-77

Kaczorowski GJ, Slaughter RS, King VF, Garcia ML (1989) Inhibitors of sodium-calcium exchange: identification and development of probes of transport activity. Biochim Biophys Acta 988:287-302.

Kater SB, Mills LR (1991) Regulation of growth cone behavior by calcium. J Neurosci 11:891-899.

Kater S, Mattson M, Cohan C, Connor J (1988) Calcium regulation of the neuronal growth cone. Trends Neurosci 11:315-321.

Lansman JB, Hess P, Tsien RW (1986) Blockade of current through single calcium channels by $\mathrm{Cd}^{2+}, \mathrm{Mg}^{2+}$, and $\mathrm{Ca}^{2+}$. Voltage and concentration dependence of calcium entry into the pore. J Gen Physiol $88: 321-347$.

Ledeen RW (1984) Biology of gangliosides: neuritogenic and neuronotrophic properties. J Neurosci Res 12:147-159.

Ledeen RW, Wu G (1992) Ganglioside function in the neuron. Trends Glycosci Glycotech 4:174-187.

Manev H, Favaron M, Vicini S, Guidotti A, Costa E (1990) Glutamate-induced neuronal death in primary cultures of cerebellar granule cells: protection by synthetic derivatives of endogenous sphingolipids. Biochem Cell Biol 68:154-160.

Masco D, Van de Walle M, Spiegel S (1991) Interaction of ganglioside GM1 with the B subunit of cholera toxin modulates growth and differentiation of neuroblastoma N 18 cells. J Neurosci 1 1:2443-2452.

Mattson MP, Guthrie PB, Mills LR (1988) Components of neurite outgrowth that determine neuronal cytoarchitecture: influence of calcium and the growth substrate. J Neurosci Res 20:331-345.

Merritt JE, Jacob R, Hallam TJ (1989) Use of manganese to discriminate between calcium influx and mobilization from internal stores in stimulated human neutrophils. J Biol Chem 264:1522-1527.

Milani D, Minozzi MC, Petrelli L, Guidolin D, Skaper SD, Spoerri PE (1992) Interaction of ganglioside GM1 with the B subunit of cholera toxin modulates intracellular free calcium in sensory neurons. J Neurosci Res 33:466-475.

Miller RJ (1987) Multiple calcium channels and neuronal function. Science 235:46-52.

Miller-Podraza H, Bradley RM, Fishman PH (1982) Biosynthesis and localization of gangliosides in cultured cells. Biochemistry 21:32603265 .

Mulhern SA, Fishman PH, Spiegel S (1989) Interaction of the B subunit of cholera toxin with endogenous ganglioside GM1 causes changes in membrane potential of rat thymocytes. J Membr Biol 109:21-28.

Olivera A, Spiegel S (1992) Ganglioside GMl and sphingolipid breakdown products in cellular proliferation and signal transduction pathways. Glycoconjugate J 9:109-117.

Pessah IN, Zimanyi I (1991) Characterization of multiple $\left[{ }^{3} \mathrm{H}\right]$ ryanodine binding sites on the $\mathrm{Ca}^{2}+$ release channel of sarcoplasmic reticulum from skeletal and cardiac muscle: evidence for a sequential mechanism in ryanodine action. Mol Pharmacol 39:679-689.

Plummer MR, Logothetis DE, Hess P (1989) Llementary propertics and pharmacological sensitivities of calcium channels in mammalian peripheral neurons. Neuron 2:1453-1463.

Rink TJ (1990) Receptor-mediated calcium entry. FEBS Lett 268 : $381-385$

Schengrund C (1990) The role(s) of gangliosides in neural differentiation and repair. A perspective. Brain Res Bull 24:131-141.

Schneider JS, Pope A, Simpson K, Taggart J, Snith MG, DiStefano L (1992) Recovery from experimental Parkinsonism in primates with GM1 ganglioside treatment. Science 256:843-846.

Slomiany BL, Liu J, Yao P, Slomiany A (1992) Modulation of dihydropyridine-sensitive gastric mucosal calcium channcls by GM1ganglioside. Int J Biochem 24:1289-1294.

Smith JB, Cragoe EJ, Smith L (1987) $\mathrm{Na}^{+} / \mathrm{Ca}^{2+}$ antiport in cultured arterial smooth muscle cells. Inhibition by magnesium and other divalent cations. J Biol Chem 262:11988-11994.

Spedding M, Paoletti IR (1992) Classification of calcium channels and the sites of action of drugs modifying channel function. Pharmacol Rev 44:363-376.

Spiegel S (1988) Insertion of ganglioside GMl into rat glioma C6 cells 
renders them susceptible to growth inhibition by the B subunit of cholera toxin. Biochim Biophys Acta 969:249-256.

Spiegel S (1989a) Possible involvement of a GTP-binding protein in a late event during endogenous ganglioside-modulated cellular proliferation. J Biol Chem 264:6766-6772.

Spiegel S (1989b) Inhibition of protein kinase C-dependent cellular proliferation by interaction of endogenous ganglioside GM1 with the B subunit of cholera toxin. J Biol Chem 264:16512-16517.

Spiegel S (1990) Cautionary note on the use of the B subunit of cholera toxin as a ganglioside GM1 probe: detection of cholera toxin A subunit in $B$ subunit preparations by a sensitive adenylate cyclase assay. $\mathrm{J}$ Cell Biochem 42:143-152.

Spiegel S (1991) Novcl rcgulation of cell growth by endogenous gangliosides. In: CRC Uniscience, Vol II, Growth regulation and carcinogenesis (Paukovits WR, ed), pp 111-119. Boca Raton, FL: CRC.

Spiegel S, Fishman PH (1987) Gangliosides as bimodal regulators of cell growth. Proc Natl Acad Sci USA 84:141-145.

Spiegel S, Panagiotopoulos C (1988) Mitogenesis of 3T3 fibroblasts induced by endogenous ganglioside is not mediated by cAMP, protein kinase C, or phosphoinositides turnover. Exp Cell Res 177:414-427.
Spiegel S, Fishman PH, Weber RJ (1985) Direct evidence that endogenous ganglioside GM1 can mediate thymocyte proliferation. Science 230:1283-1287.

Spoerri PE, Dozier AK, Roisen FJ (1990) Calcium regulation of neuronal differentiation: the role of calcium in GM1-mediated neuritogenesis. Dev Brain Res 56:177-188.

Svennerholm L (1963) Chromatographic separation of human brain gangliosides. J Neurochem 10:612-623.

Tsien RW, Lipscombe D, Madison DV, Bley K, Fox AP (1988) Multiple types of neuronal calcium channels their selective modulation. Trends Neurosci 11:431-438.

Van de Walle M, Fass R, Shiloach J (1990) Production of cholera toxin subunit $\mathrm{B}$ by a mutant strain of Vibrio cholera. Applicd Microbiol Biotechnol 33:389-394.

Wu G, Vaswani KK, Lu ZH, Ledeen RW (1990) Gangliosides stimulate calcium flux in Neuro-2A cells and require exogenous calcium for neuritogenesis. J Neurochem 55:484-491.

Zhang H, Desai NN, Olivera A, Seki T, Brooker G, Spiegel S (1991) Sphingosine-1-phosphate, a novel lipid, involved in cellular proliferation. J Cell Biol 114:155-167. 